https://nv.nltu.edu.ua

https://doi.org/10.36930/40310506

Article received 15.11.2021 p.

@ Correspondence author

Article accepted 25.11.2021 p.

UDC 574.45

\title{
ОЦІНЮВАННЯ ЗАПАСІВ ВУГЛЕЦЮ У ФІТОМАСІ ЛІСОВИХ НАСАДЖЕНЬ ЗАПОВІДНИХ ТЕРИТОРІЙ УКРАЇНСЬКИХ КАРПАТ
}

Визначено запаси вуглецю у різних компонентах фітомаси лісових насаджень (хвоя/листя, гілки, стовбур, корені, підріст, підлісок і живий надгрунтовий покрив) заповідних територій Українських Карпат методом "знизу-вгору" на основі прямих підрахунків запасів окремих складників фітомаси і щільності деревини за породами. Для обчислення маси компонентів фітомаси використано алометричні рівняння. Заміри та встановлення лісотаксаційних показників дерев, а також їх геолокацію (координата кожного дерева) проведено на 54 пробних площах заповідної зони Національного природного парку (НПП) "Сколівські Бескиди" та 20 пробних площах природного заповідника (ПЗ) "Горгани" з використанням Field-Mар, прив'язку пробних площ до системи координат (WGS-84) здійснено GPS-навігатором. Отримані лісотаксаційні заміри попередньо оброблено у середовищі MS Excel, пізніше їх вносили у базу даних у середовищі MS Access для подальшого аналізу. За базову одиницю розрахунку запасу вуглецю для насаджень взято пробну площу із врахуванням іiї лісівничо-таксаційних показників (породний склад, середній вік, клас бонітету, відносна повнота деревостану). Унаслідок обчислень встановлено, що щільність запасів вуглецю у фітомасі лісових насаджень НПП "Сколівські Бескиди" становить 244 т/га, а у фітомасі П3 "Горгани" - 205 т/га. Запас вуглецю у фітомасі насаджень бука лісового у НПП "Сколівські Бескиди" становить 1,1 Мт, а у фітомасі насаджень ялиці білої - 0,3. Визначено запаси вуглецю у різних компонентах фітомаси лісових насаджень заповідних територій Українських Карпат методом "знизу-вгору" на основі прямих підрахунків запасів окремих складників фітомаси і щільності деревини за породами з використанням алометричних рівнянь. На основі експериментальних досліджень (54 пробні площі заповідної зони Національного природного парку "Сколівські Бескиди" та 20 пробних площ природного заповідника "Горгани") встановлено, що щільність запасів вуглецю у фітомасі лісових насаджень НПП "Сколівські Бескиди" 244 т/га, а у фітомасі ПЗ "Горгани" становить 205 т/га. Найбільша щільність запасів вуглецю наявна у букових насадженнях.

Ключові слова: вуглець фітомаси; ліс; заповідні ліси; щільність запасів вуглецю.

\section{Вступ / Introduction}

Сьогодення вимагає від людства стримування зміни клімату, щоб зменшити негативний вплив на екосистеми Землі. Лісові масиви займають важливу нішу у процесі впливу на зміну клімату, оскільки вони поглинають вуглекислий газ з атмосфери та утримують вуглець у фітомасі десятки років. Зменшення площі лісів та їх деградація призводять до емісій вуглекислого газу з фітомати. Тому ліси потребують адаптації системи заходів, які спрямовані на ефективне ведення лісового господарства для запобігання зменшенню їх фітомаси, що дасть змогу послабити антропогенний вплив на атмосферу Землі. Розширене відтворення лісів і підвищення їх стійкості та життєздатності дасть змогу збільшити поглинання ними вуглекислого газу. Ліси вилучають приблизно третю частину вуглецю, який виділяється внаслідок спалювання викопного палива, тому мають істотний вплив на глобальний вуглецевий цикл [3].

Лісові масиви за своїми функціями мають важливе економічне та природоохоронне значення, а також відіграють значну роль у вуглецевому балансі наземних екосистем та виконанні країнами їх зобов'язань щодо контролю емісій парникових газів у межах Паризької кліматичної угоди. Це спонукає країни здійснювати моніторинг лісів, фіксувати зміни та ефективно управляти ними, інформувати міжнародні організації про стан лісів.

Від наявності засобів чіткого контролю, повноти i достовірності звітної інформації буде залежати участь нашої держави в міжнародних процесах з питань змін клімату, а також торгівлі квотами на емісії парникових газів. Оцінювання динаміки вуглецю в лісових екосистемах є важливою частиною ведення національного кадастру емісій та поглиначів парникових газів. Тому проблема оцінювання величини депонування вуглецю в лісових насадженнях є актуальною.

\section{Інформація про авторів:}

Токар Ольга Євгенівна, канд. техн. наук, доцент, кафедра міжнародної інформації. Email: olha.y.tokar@lpnu.ua; https://orcid.org/0000-0001-9428-2472

Король Микола Михайлович, канд. с.-г. наук, доцент, кафедра лісової таксації та лісовпорядкування. Email: nikkorol@ukr.net; https://orcid.org/0000-0002-9023-0840

Густі Микола Іванович, д-р техн. наук, професор, кафедра міжнародної інформації. Email: mykola.i.husti@Ipnu.ua; https://orcid.org/0000-0002-2576-9217

Цитування за Дсту: Токар О. Є., Король М. М., Густі М. І. Оцінювання запасів вуглецю у фітомасі лісових насаджень заповідних територій Українських Карпат. Науковий вісник НЛтУ України. 2021, т. 31, № 5. С. 42-46.

Citation APA: Tokar, O. Ye., Korol, M. M., \& Gusti, M. I. (2021). Estimation of carbon stocks in phytomass of forest stands of protected areas in the Ukrainian Carpathians. Scientific Bulletin of UNFU, 31(5), 42-46. https://doi.org/10.36930/40310506 
Об'єкт дослідження - процеси кругообігу вуглецю в лісових екосистемах.

Предмет дослідження - методи і засоби нагромадження вуглецю в лісових насадженнях та математичні моделі цих процесів.

Мета роботи - визначити запаси та щільність вуглецю у фітомасі лісових насаджень заповідних територій Українських Карпат.

Для досягнення зазначеної мети визначено такі основні завдання дослідження:

- проаналізувати основні літературні джерела з оцінювання запасів вуглецю в лісових насадженнях;

- доповнити розроблену базу даних про лісові насадження зібраними даними про деревостан заповідних територій;

- доповнити розроблену базу даних про лісові насадження математичними моделями запасів вуглецю;

- здійснити обчислення запасів та щільності вуглецю у фітомасі лісових насаджень заповідних територій.

Наукова новизна отриманих результатів дослідження - вперше визначено особливості підвищення точності оцінювання запасів вуглецю у фітомасі лісових насаджень за рахунок обчислень на рівні елементарних об'єктів (дерево, пробна площа).

Практична значущість результатів дослідження отримані оцінки запасів вуглецю в лісових насадженнях заповідних територій можуть бути використані для підтримки прийняття рішень у галузі лісового господарства та природоохоронної діяльності.

Аналіз останніх досліджень та публікацій. Питанню дослідження вуглецевого балансу лісових насаджень приділяють велику увагу. Оцінюванню запасів вуглецю у фітомасі лісів присвячено значну кількість сучасних наукових досліджень. Варто відзначити роботи $[2,4,8,9,11]$ серед закордонних фахівців та $[1,5,6$, $7,10]$ серед вітчизняних науковців. Оцінку надземної фітомаси спілих і старовікових смереково-ялинових лісів Горган подано в [4], оцінку запасів вуглецю в лісових екосистемах Східних Бескидів наведено в [10], а ці показники щодо лісів України - в $[1,5]$. Проте не оцінено запаси вуглецю у лісових насадженнях заповідних територій, зокрема Українських Карпат. Поширеним методом визначення фітомаси та запасів вуглецю у лісових екосистемах $є$ метод аналізу модельних дерев насадження, який забезпечує високу точність [6]. Проте цей метод потребує значних затрат ресурсів. У цьому дослідженні використано інший метод, який також адекватно описує оцінки фітомаси та розрахунок вмісту вуглецю, що грунтується на використанні регресійних рівнянь (залежність фітомаси від деревної породи, середнього віку, класу бонітету, відносної повноти насаджень) [7]. Обчислення запасу вуглецю у фітомасі насаджень базуються на лісотаксаційних показниках дерев закладених пробних площ на заповідних територіях, на відміну від розрахунку запасу вуглецю в лісових екосистемах, де базовою одиницею взято лісотаксаційний виділ [10].

Матеріали та методи дослідження. Дослідження виконано за матеріалами 54 пробних площ (кругові пробні площі 0,05 га), що закладені у заповідній зоні Національного природного парку "Сколівські Бескиди" площею 7046,6 га та на 20 пробних площах Природного заповідника "Горгани" площею 2483,8 га.

Заміри висоти, діаметра та інших лісотаксаційних показників дерев із зазначенням координат на дослід- них ділянках та їх картування на площі проводили з використанням технології Field-Map, прив'язку пробних площ до системи координат (WGS-84) здійснювали GPS-навігатором. Польові матеріали обробляли у середовищі MS Excel. Зібрані дані про лісові насадження (порода, вік, клас бонітету, відносна повнота на інші показники) оперативно вносились в базу даних в середовищі MS Access, за основу якої взято методику, що застосовувалася під час інвентаризації Угольсько-Широколужанського букового пралісу в Карпатському біосферному заповіднику [12], для статистичного опрацювання та визначення запасів вуглецю у фітомасі насаджень.

Процеси депонування вуглецю в лісових екосистемах залежать від багатьох чинників (віку насаджень, породного складу, відносної повноти, продуктивності, природних та антропогенних збурень тощо). Тому для оцінювання запасів вуглецю в лісових насадженнях у дослідженні використано детальну інформацію про стан лісів, характеристику насаджень, математичні моделі, що дало змогу з високою точністю визначити запаси вуглецю у фітомасі лісових насаджень досліджуваних ділянок. Запаси вуглецю визначено для таких компонентів фітомаси: надземна та підземна частини деревостану (хвоя/листя, гілки, стовбур, корені), піднаметова рослинність (підріст, підлісок і живий надгрунтовий покрив). За базову одиницю розрахунку запасу вуглецю для насаджень взято пробну площу із врахуванням іiі лісівничо-таксаційних показників (породний склад, середній вік, клас бонітету, відносна повнота деревостану). Використано метод "знизу-вгору" для обчислення запасів вуглецю за принципом збирання та агрегації інформації пробних площ. Хоча цей метод $\epsilon$ трудомістким, проте дає змогу отримувати достовірніші результати, ніж метод "зверху-вниз" із використанням узагальнених даних [1].

Розрахунки запасу надземної та підземної фітомаси виконано з використанням даних статистичної інвентаризації пробних площ заповідних територій та регресійних співвідношень (алометричних рівнянь) $[6,7,13]$, що пов'язують запас стовбурової деревини, масу абсолютно сухої речовини надземної, підземної частин деревостану, а також піднаметову рослинність із запасами вуглецю:

$$
X_{g}+X_{w}=G S \cdot R_{f} \cdot k_{1}+G S \cdot\left(R_{b r}+R_{s t}+R_{b l}\right) \cdot k_{2}+R_{u s} \cdot k_{1},
$$

де: $X_{g}$ - запас вуглецю у фітомасі зелених органів деревостанів, т/га; $X_{w}$ - запас вуглецю у фітомасі деревини та коренів, т/га; $G S$ - запас стовбурової деревини, м ${ }^{3} /$ га; $R_{f}, R_{b r}, R_{s t}, R_{b l}, R_{u s}$ - алометричні рівняння для визначення компонентів фітомаси (відповідно для листя/хвої, гілок, стовбура, коріння та піднаметової рослинності), які враховують відношення фітомаси певної фракції в абсолютно сухому стані до запасу стовбурової деревини деревостану, причому для піднаметової рослинності ці коефіцієнти відображають пряму оцінку фітомаси; $k_{1}, k_{2}$ - конверсійні коефіцієнти, що переводять одиниці абсолютно сухої речовини в одиниці вуглецю.

Детальний опис методу обчислень, вигляд та величини коефіцієнтів алометричних, та конверсійних коефіцієнтів, які використано в цій роботі, наведено в роботі [13]. 


\section{Результати дослідження та їх обговорення / Research results and their discussion}

Національний природний парк "Сколівські Бески$\partial \boldsymbol{u}^{\prime \prime}$. Найбільшу частку в структурі фітомаси насаджень у заповідній зоні НПП "Сколівські Бескиди" становлять букові деревостани - $62 \%$ (4417,68 га), ялини європейської - 16 \% (1106,3 га) та ялиці білої - 13 \% (887,23 га), а найменшу частку 5 та $3 \%$ займають відповідно клен-явір та клен гостролистий. Продуктивність насаджень є високою: деревні породи ростуть за класами бонітету I ${ }^{\mathrm{a}}$ - II. Вік дерев лежить в діапазоні 45-156 років, а показник відносної повноти змінюється від 0,41 до 0,89 .

Результати обчислень запасів вуглецю у фітомасі лісових насаджень НПП "Сколівські Бескиди" за фракціями (листя, гілки, стовбур, підріст і підлісок, живий надгрунтовий покрив) подано у вигляді фрагментів звітів з бази даних за пробними площами відповідно до складу насадження (рис. 1) і за породами загалом (рис. 2).

\begin{tabular}{|c|c|c|c|c|c|c|c|c|c|c|c|}
\hline № ПП порода & $\begin{array}{l}\kappa-m b \\
\text { depe }\end{array}$ & $\begin{array}{c}\text { площа } \\
\text { га }\end{array}$ & $\begin{array}{c}\text { а, запас } \\
\text { стовбурно } \\
\text { деревини, } \\
\text { м3 }\end{array}$ & $\begin{array}{l}\text { oï } 3 a r \\
\text {. }\end{array}$ & $\operatorname{lac} \phi i$ & imoмacı & u наса & 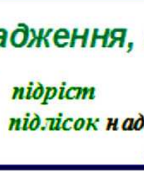 & $\begin{array}{l}m / 2 a \\
\text { живий } \\
\text { дгрунтовий } \\
\text { покрив }\end{array}$ & $\begin{array}{l}\text { запас } \\
\text { вуглецю у } \\
\text { фітомасі, } \\
\quad m \\
\text { сй }\end{array}$ & $\begin{array}{l}\text { щільність } \\
\text { запасів } \\
\text { вуелецю } \\
\text { m/2а }\end{array}$ \\
\hline 1 & 22 & 0.05 & 18.3368 & 4.7729 & 44.3850 & 191.2284 & 63.81 & 3.1453 & 3.6208 & 7.37 & 147 \\
\hline Клен гостролистий & 2 & .0045 & 1.5270 & .2236 & 4.7429 & 17.5615 & 6.24 & & & .68 & \\
\hline Ялина єеропейсьюа & 7 & .0159 & 5.6168 & 2.9107 & 4.8761 & 44.9387 & 11.82 & & & 1.58 & \\
\hline Буклісовий & 13 & .0295 & 11.1930 & 1.6387 & 34.7660 & 128.7281 & 45.75 & & & 5.11 & \\
\hline 2 & 24 & 0.05 & 33.1269 & 5.8528 & 73.3136 & 386.3419 & 124.20 & 2.1831 & 3.0837 & 14.00 & 280 \\
\hline Буклісовий & 23 & .0479 & 30.6921 & 4.5199 & 71.1587 & 367.7745 & 118.87 & & & 13.33 & \\
\hline Ялина єєропейська & 1 & .0021 & 2.4348 & 1.3329 & 2.1549 & 18.5674 & 5.33 & & & .67 & \\
\hline 3 & 18 & 0.05 & 33.9466 & 10.0842 & 81.9478 & 336.2181 & 109.01 & 3.4677 & 3.7555 & 12.96 & 259 \\
\hline Буклісовий & 13 & .0361 & 19.1385 & 2.6540 & 69.5407 & 215.9108 & 78.53 & & & 8.78 & \\
\hline Ялина єєропейська & 4 & .0111 & 12.2825 & 6.1629 & 10.2909 & 99.7879 & 25.28 & & & 3.47 & \\
\hline Ялиця біла & 1 & .0028 & 2.5256 & 1.2673 & 2.1161 & 20.5193 & 5.20 & & & .71 & \\
\hline
\end{tabular}

Рис. 1. Таблиця даних зі звіту бази даних про компоненти фітомаси, запас та щільність запасів вуглецю у фітомасі насаджень НПП "Сколівські Бескиди" на пробних площах / A data table from the report of the database on the phytomass components and carbon stock in phytomass of forest stands at the sample plots in the Skole Beskids National Nature Park

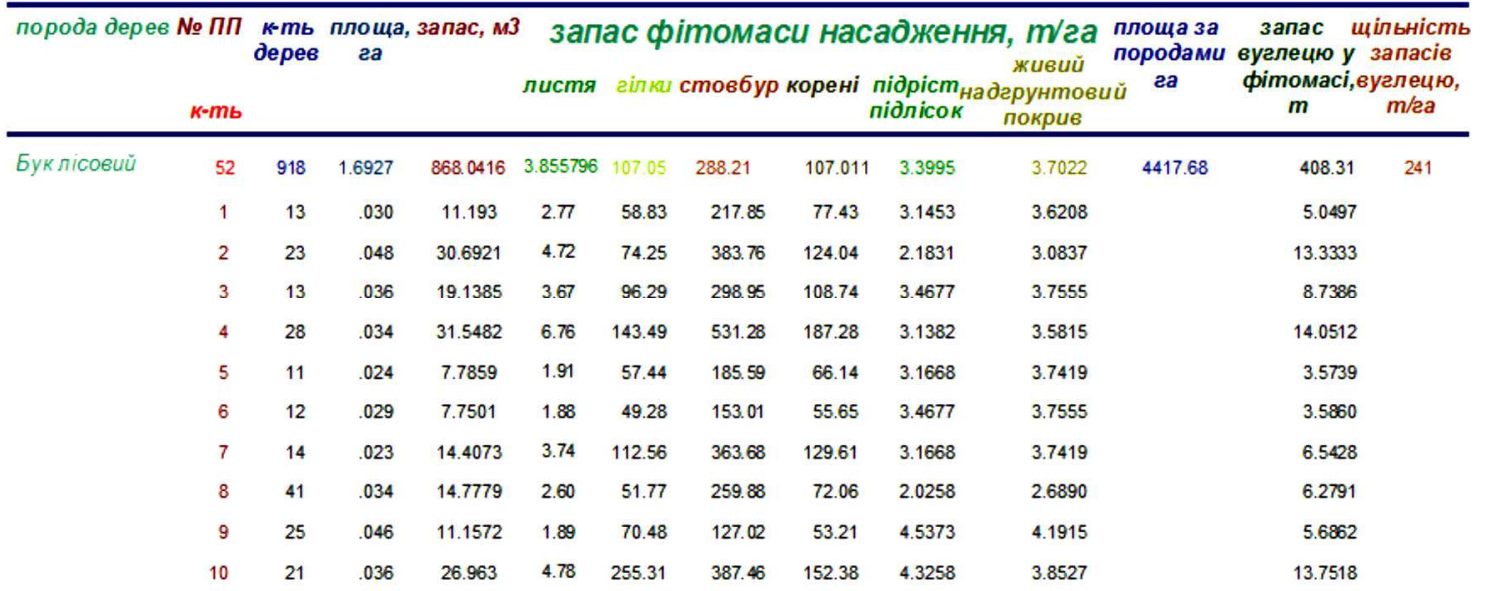

Pис. 2. Таблиця даних зі звіту бази даних про компоненти фітомаси, запас та щільність запасів вуглецю у фітомасі насаджень НПП "Сколівські Бескиди" за породами / A data table from the report of the database on the phytomass components and carbon stock in phytomass of forest stands in the Skole Beskids National Nature Park by tree species

Встановлено, що для вкритих лісовою рослинністю ділянок НПП "Сколівські Бескиди" загальною площею 7046,6 га запас органічного вуглецю у фітомасі насаджень становить 1,7 Мт. Щільність вуглецю на 1 га вкритих лісовою рослинністю ділянок становить 244 т. Найбільші запаси вуглецю - 1,1 Мт - зосереджено в насадженнях бука лісового, що займає площу 4417,68 га та ялиці білої - 0,3 Мт. У табл. 1 подано запаси вуглецю, акумульованого різними породами насаджень НПП "Сколівські Бескиди".

Природний заповідник "Горгани". Найбільшу частку в структурі фітомаси насаджень заповідника "Горгани" становлять деревостани ялини європейської $74 \%$ (1815,73 га), ялиці білої - 17 \% (432,32 га) та бука лісового - 5 \% (125,57 га), а найменшу частку (по $1 \%$ ) займають відповідно береза повисла, клен-явір, клен гостролистий та горобина звичайна. Щодо продуктивності насаджень, то найбільша частка деревостанів належить до класу бонітету II (39\%) та класів III i IV (46 \%), найменша частка припадає на деревостани бонітету I ${ }^{\mathrm{a}}$, I та V (по 2, 4 і 9 \% відповідно). Середній вік насаджень становить 115-225 років, а показник відносної повноти деревостану змінюється від 0,71 до 0,96.

Встановлено, що для вкритих лісовою рослинністю ділянок заповідника "Горгани" загальною площею 2483,8 га запас органічного вуглецю у фітомасі насаджень становить 0,51 Мт. Щільність вуглецю на 1 га вкритих лісовою рослинністю ділянок становить 205 т. Найбільші запаси вуглецю - 0,3 Мт - зосереджено в насадженнях ялини європейської, що займає площу 
1815,73 га. У табл. 2 подано запаси вуглецю, акумульованого різними породами насаджень заповідника "Горгани".

Табл. 1. Запаси вуглецю, акумульованого основними лісотвірними породами насаджень НПП "Сколівські Бескиди" / Carbon stocks accumulated in phytomass of the main forest-forming tree species of the forest stands in the Skole Beskids National Nature Park

\begin{tabular}{|c|c|c|}
\hline Деревна порода & $\begin{array}{c}\text { Площа за } \\
\text { породами, га }\end{array}$ & $\begin{array}{c}\text { Запас вуглецю } \\
\text { у фітомасі, т }\end{array}$ \\
\hline Бук лісовий & 4417,68 & 1064660,88 \\
\hline Клен гостролистий & 241,83 & 64084,95 \\
\hline Клен-явір & 393,56 & 104293,4 \\
\hline Ялина європейська & 1106,3 & 164838,7 \\
\hline Ялиця біла & 887,23 & 323838,95 \\
\hline Разом & $\mathbf{7 0 4 6 , 6}$ & $\mathbf{1 7 2 1 7 1 6 , 8 8}$ \\
\hline
\end{tabular}

Табл. 2. Запаси вуглецю, акумульованого різними лісотвірними породами природного заповідника "Горгани" / Carbon stocks accumulated in phytomass of the main forestforming tree species of the forest stands in Gorgany Nature Reserve

\begin{tabular}{|c|c|c|}
\hline Деревна порода & $\begin{array}{c}\text { Площа за } \\
\text { породами, га }\end{array}$ & $\begin{array}{c}\text { Запас вуглецю у } \\
\text { фітомасі, т }\end{array}$ \\
\hline Береза повисла & 24,97 & 6467,23 \\
\hline Бук лісовий & 125,57 & 64213,05 \\
\hline Горобина звичайна & 25,53 & 1659,45 \\
\hline Клен гостролистий & 23,29 & 1785,567 \\
\hline Клен-явір & 25,87 & 3414,84 \\
\hline Сосна кедрова європейська & 10,52 & 3103,4 \\
\hline Ялина європейська & 1815,73 & 325887,5 \\
\hline Ялиця біла & 432,32 & 103210,2 \\
\hline Разом & $\mathbf{2 4 8 3 , 8}$ & $\mathbf{5 0 9 7 4 1 , 2}$ \\
\hline
\end{tabular}

Обговорення результатів дослідження. Отримана в цьому дослідженні оцінка щільності вуглецю у фітомасі лісових насаджень для вкритих лісовою рослинністю ділянок НПП "Сколівські Бескиди", 244 тС/га, адекватна оцінці щільності запасів вуглецю в лісових екосистемах (буково-ялицевих) корінного біогеоценотичного покриву Східних Бескидів, яка включає ще стовбуровий фітодетрит, підстику та грунт і становить 262/га [1].

Наша оцінка щільності вуглецю у фітомасі деревостанів вкритих лісовою рослинністю ділянок заповідника "Горгани", 205 т вуглецю/га, є співмірна із оцінкою надземної фітомаси спілих та старовікових смерековоялинових лісів Горган, наведеною у роботі [4], 181 та 256-303 т/га відповідно. Порівнюючи їх, варто врахувати, що надземна фітомаса у роботі [4] не містить корені, а одиницями вимірювання є тонна абсолютно сухої деревини на 1 га.

Щільність запасів вуглецю у насадженнях НПП "Сколівські Бескиди" є більшою, ніж у насадженнях ПЗ "Горгани" завдяки панівній породі бука лісового на ділянці та високій продуктивності деревостанів. Для порівняння цей показник у лісах України становить 65 т/га [5]. Отже, ліси заповідних територій Українських Карпат краще депонують вуглець, ніж у середньому ліси України.

3 огляду на отримані результати, вважаємо, що основні заходи для збільшення наявних запасів вуглецю у фітомасі лісових насаджень заповідних територій повинні бути спрямовані на збереження структури первинного лісового покриву.

\section{Висновок / Conclusions}

Оцінювання запасів вуглецю у фітомасі лісових насаджень потребує використання великого масиву вхідних даних. Для отримання точних та об'єктивних результатів доцільно використовувати підхід, який базується на даних статистичної інвентаризації лісових ділянок. Проведені розрахунки використовують метод обчислень "знизу-вгору" (одне дерево - пробна площа лісова ділянка) та грунтуються на застосуванні баз даних пробних площ, що дає змогу достовірніше розрахувати запас фітомаси та вуглецю у різних компонентах фітомаси насадження. На прикладі 54 пробних площ заповідної зони НПП "Сколівські Бескиди" та 20 пробних площ ПЗ "Горгани" здійснено оцінку запасів та щільності запасів вуглецю у різних компонентах фітомаси насаджень як за породами, так і для пробних площ, а також ділянок загалом. Щільність запасів вуглецю у насадженнях НПП "Сколівські Бескиди" становить 244 т/га, а у насадженнях ПЗ "Горгани" - 205 т/га. Ці показники набагато вищі за показник у лісах України, що свідчить про те, що заповідні території Українських Карпат краще депонують вуглець, ніж у середньому ліси України. Отримані оцінки будуть корисними для прийняття управлінських рішень щодо лісів заповідних територій. У подальшому оцінка запасів вуглецю буде доповнена аналізом похибок.

\section{References}

1. Buksha, I. F., \& Pasternak, V. P. (2005). Inventaryzatsiia ta monitorynh parnykovykh haziv u lisovomu hospodarstvi: monohrafiia. KHarkiv: KHNAU, 125 p. [In Ukrainian].

2. Ciais, P., Schelhaas, M., Zaehle, S., et. al. (2008). Carbon accumulation in European forests. Nature Geosci, 1, 425-429. https://doi.org/10.1038/ngeo233

3. Grassi, G., House, J., Dentener, F., et. al. (2017). The key role of forests in meeting climate targets requires science for credible mitigation. Nature Clim Change, 7, 220-226. https://doi.org/10.1038/nclimate3227

4. Keeton, W. S., Chernyavskyy, M., Gratzer, G., et. al. (2010). Structural characteristics and aboveground biomass of old-growth spruce-fir stands in the eastern Carpathian mountains, Ukraine. Plant Biosystems, 144(1), 148-159. https://doi.org/10.1080/11263500903560512

5. Lakida, P. I. (2001). Dinamika zapasov ugleroda v lesakh Ukrainy. Problemy lesovedeniia i lesovodstva: sb. nauch. tr., Gomel, issue 56, 86-90. [In Russian].

6. Lakida, P. I. (2002). Fitomasa lisiv Ukraini: monografiia. Ternopil: Zbruch, 256 p. [In Ukrainian].

7. Lakida, P., Nilsson, S., \& Shvidenko, A. (1996). Estimation of forest phytomass for selected countries of the former European U.S.S.R. Biomass and Bioenergy, 11(5), 371-382.

8. Lesiv, M., Shvidenko, A., Schepaschenko, D., et. al. (2019). A spatial assessment of the forest carbon budget for Ukraine. Mitig Adapt Strateg Glob Change, 24, 985-1006. https://doi.org/10.1007/s11027-018-9795-y

9. Liski, J., Lehtonen, A., Palosuo, T., et. al. (2006). Carbon accumulation in Finlands forests 1922-2004 - an estimate obtained by combination of forest inventory data with modelling of biomass, litter and soil. Annals of Forest Science, 63(7), 687-697. https://doi.org/10.1051/forest:2006049

10. Shpakivska, I. M., \& Maryskevych, O. H. (2009). Otsinka zapasiv vuhletsiu v lisovykh ekosystemakh Skhidnykh Beskydiv. Naukovyi visnyk UkrNDILHA: Lisivnytstvo i ahrolisomelioratsiia, 115, 176-180. [In Ukrainian].

11. Sierra, C. A., del Valle, J. I., \& Restrepo, H. I. (2012). Total carbon accumulation in a tropical forest landscape. Carbon Balance Manage, 7(12). https://doi.org/10.1186/1750-0680-7-12 
12. Tinner, Rafaela, Kommarmot, Brigitte, Brang, Peter, \& Brendli, Urs-Beat. (2010). Metodychni vkazivky zi statystychnoi inventaryzatsii Uholsko-Shyrokoluzhanskoho bukovoho pralisu. Versiia 1.3 vid 30.04.2010 na osnovi pilotnoi inventaryzatsii 2009. Shveitsarskyi federalnyi instytut doslidzhen lisu, snihu i landshaftiv WSL, Birmensdorf. Retrieved from: http:/www.wsl.ch/. [In Ukrainian].
13. Tokar, O. Ye., Korol, M. M., Shpakivska, I. M., \& Dychkevych, V. M. (2014). Vyznachennia zapasiv vuhletsiu u fitomasi lisovykh nasadzhen iz vykorystanniam informatsiinykh tekhnolohii. Scientific Bulletin of UNFU, 24(4), 351-358. Retrieved from: https://nv.nltu.edu.ua/Archive/2014/24_4/351_Tok.pdf. Ukrainian]

O. Ye. Tokar', M. M. Korol', M. I. Gusti'

${ }^{1}$ Lviv Polytechnic National University, Lviv, Ukraine ${ }^{2}$ Ukrainian National Forestry University, Lviv, Ukraine

\section{ESTIMATION OF CARBON STOCKS IN PHYTOMASS OF FOREST STANDS OF PROTECTED AREAS IN THE UKRAINIAN CARPATHIANS}

We estimated carbon stocks in such components of phytomass of forest stands as needles/leaves, branches, stem, roots, understory, shrubs, and forest floor of protected areas of the Ukrainian Carpathians applying bottom-up approach based on direct calculations of stocks of individual phytomass components. We used allometric equations for calculating the mass of phytomass components. We carried out measurements and estimations of forest inventory indicators of trees, as well as geolocation of the trees (coordinates of each tree in WGS-84 coordinate system) on 54 sample plots of the protected area of the Skole Beskids National Nature Park (NNP) and 20 sample plots of (NR) Gorgany Nature Reserve using Field-Map and GPS-navigator. We pre-processed the obtained measurements of the forest inventory indicators in MS Excel and uploaded them into database in MS Access for further analysis. We used a sample plot taking into account its silvicultural and taxonomic indicators such as species composition, average age, site index, relative stocking as the basic unit for calculating the carbon stock for the forest stands. As a result of calculations, we found that the density of carbon stocks in the phytomass of forest stands of Skole Beskids NPP is $244 \mathrm{t} / \mathrm{ha}$, and $205 \mathrm{t} / \mathrm{ha}$ in the phytomass of Gorgany NR. The carbon stock in the phytomass of European beech stands in Skole Beskids NNP is $1.1 \mathrm{Mt}$, and $0.3 \mathrm{Mt}$ in the phytomass of silver fir stands, the total carbon stock is $1.7 \mathrm{Mt}$. The carbon stock in the phytomass of European spruce stands in Gorgany NR is $0.3 \mathrm{Mt}$, and $0.1 \mathrm{Mt}$ in the phytomass of silver fir stands, the total carbon stock is $0.51 \mathrm{Mt}$. The density of carbon stocks in forest stands of Skole Beskids NNP is higher than in the forest stands of Gorgany NR due to prevailing beech stands on the site and high productivity of the stands. In general, the carbon stocks density in the phytomass of forest stands of Skole Beskids NNP and Gorgany NR are considerably higher than the carbon stocks density averaged over all forest stands in Ukraine, $65 \mathrm{t} / \mathrm{ha}$. As a further development of this study, we plan to analyze uncertainties in the carbon stock estimates.

Keywords: phytomass carbon; forest; protected forest; carbon stocks density. 